\title{
Stable carbon and oxygen isotope study on benthic foraminifera: Implication for microhabitat preferences and interspecies correlation
}

\author{
Ajoy K Bhaumik ${ }^{1, *}$ (®), Shiv Kumar ${ }^{1}$, Shilpi Ray ${ }^{1}$, G K Vishwakarma ${ }^{2}$, \\ Anil K Gupta ${ }^{3,4}$, Pushpendra Kumar ${ }^{5}$ and Kalachand Sain ${ }^{6}$ \\ ${ }^{1}$ Department of Applied Geology, Indian Institute of Technology (Indian School of Mines), Dhanbad, Jharkhand \\ 826004 , India. \\ ${ }^{2}$ Department of Applied Mathematics, Indian Institute of Technology (Indian School of Mines), \\ Dhanbad, Jharkhand 826004 , India. \\ ${ }^{3}$ Wadia Institute of Himalayan Geology, 33 GMS Road, Dehradun 248 001, India. \\ ${ }^{4}$ Department of Geology and Geophysics, Indian Institute of Technology, Kharagpur 721 302, India. \\ ${ }^{5}$ Unconventional Resources Group, Keshav Dev Malviya Institute of Petroleum Exploration, Oil and Natural Gas \\ Corporation Ltd., 9, Kaulagarh Road, Dehradun 248 195, India. \\ ${ }^{6}$ Gas-Hydrate Group, CSIR-National Geophysical Research Institute, Uppal Road, Hyderabad 500 007, India. \\ ${ }^{*}$ Corresponding author. e-mail: ajoyism@gmail.com
}

MS received 24 May 2016; revised 7 February 2017; accepted 10 February 2017; published online 24 July 2017

Stable isotopes of benthic foraminifera have widely been applied in micropalaeontological research to understand vital effects in foraminifera. Isotopic fractionations are mainly controlled by ontogeny, bottom/pore water chemistry, habitat preference, kinetic effect and respiration. Discontinuous abundance of a species for isotopic analysis has forced us to select multiple species from down-core samples. Thus standardisation factors are required to convert isotopic values of one species with respect to other species. The present study is pursued on isotopic values of different pairs of benthic foraminifera from the KrishnaGodavari basin and Peru offshore to understand habitat-wise isotopic variation and estimation of isotopic correction factors for the paired species (Cibicides wuellerstorfi-Bulimina marginata, Ammonia spp.Loxostomum amygdalaeformis and Bolivina seminuda-Nonionella auris). Infaunal species (B. marginata, Ammonia spp. and $N$. auris) show a lighter carbon isotopic excursion with respect to the epifaunal to shallow infaunal forms (C. wuellerstorfi, L. amygdalaeformis and B. seminuda). These lighter $\delta^{13} \mathrm{C}$ values are related to utilisation of $\mathrm{CO}_{2}$ produced by anaerobic remineralisation of organic matter. However, enrichment of $\delta^{18} \mathrm{O}$ for the deeper microhabitat (bearing lower $\mathrm{pH}$ and decreased $\mathrm{CO}_{3}{ }^{2-}$ ) is only recorded in case of B. marginata. It is reverse in case of $N$. auris and related to utilisation of respiratory $\mathrm{CO}_{2}$ and internal dissolve inorganic carbon pool. Estimation of interspecies isotopic correction factors for the species pairs $\left(\delta^{13} \mathrm{C}\right.$ of $C$. wuellerstorfi-B. marginata, L. amygdalaeformis-Ammonia spp., N. aurisB. seminuda) and $\delta^{18} \mathrm{O}$ of $C$. wuellerstorf - - B. marginata are statistically reliable and may be used in palaeoecological studies.

Keywords. Benthic foraminifera; oxygen and carbon isotopes; microhabitat; isotopic correction factors.

\section{Introduction}

Foraminifera, a group of unicellular eukaryotic protozoa, have widely been used in palaeoclimatic and palaeoceanographic reconstructions. Most of the foraminiferal taxa bear calcitic tests (except agglutinated and organic walled varieties) and 
test-morphology itself records their preferred environmental conditions (Corliss 1985). The stable carbon $\left({ }^{12} \mathrm{C}\right.$ and $\left.{ }^{13} \mathrm{C}\right)$ and oxygen $\left({ }^{16} \mathrm{O}\right.$ and ${ }^{18} \mathrm{O}$ ) isotopes present within the calcitic tests of foraminifera are widely used as key proxies for palaeoenvironmental interpretations (Shackleton 1974, 1977; Rathburn et al. 1996; Moodley et al. 2000; Cooke and Rohling 2001; Zachos et al. 2001; Fontanier et al. 2006; Ravelo and HillaireMarcel 2007; Bhaumik et al. 2011; Ishimura et al. 2012). The use of stable oxygen and carbon isotope values of foraminiferal tests was strengthened by the pioneering efforts of Urey (1947), McCrea (1950), Epstein et al. (1953), Emiliani (1955) and Shackleton and Opdyke (1973). These landmark studies revealed that the $\delta^{18} \mathrm{O}$ signal mainly reflects sea water temperature and fluctuation of global ice volume whereas the $\delta^{13} \mathrm{C}$ value reflects palaeoproductivity and age of the watermass (Shackleton and Opdyke 1973; Shackleton 1977; Zachos et al. 2001). However, several recent studies demonstrated that benthic foraminiferal oxygen isotope is also influenced by deep water hydrographic changes and thus might not always be used as a good indicator for ice volume estimation (Shackleton 2000; Skinner and Shackleton 2006; Elderfield et al. 2012; Rohling et al. 2014). Both carbon and oxygen isotopes may be measured on different foraminiferal carbonate species (calcite and aragonite). It is believed that fractionation of oxygen and carbon isotopes from sea/pore water to biogenic carbonate are controlled by thermodynamics and $\delta^{13} \mathrm{C}$ of dissolved inorganic carbon/carbonate in sea/pore water, respectively (Cooke and Rohling 2001; Fontanier et al. 2006; Hoogakker et al. 2010; Ishimura et al. 2012).

Isotope values of benthic foraminifera (bottom dwellers) are important tool to understand past global climate as well as their preferred microhabitat. Studies suggest that deviation in equilibrium of isotopes in foraminiferal carbonates from the sea water (vital effect) may be biased by the effects of ontogeny, respiration, symbiont photosynthesis, microhabitat, climatic variability, bottom and pore water temperature, pore water chemistry, diagenesis, $\mathrm{pH}$ of water, and changes in $\mathrm{CO}_{3}{ }^{2-}$ (Shackleton 1974; Cooke and Rohling 2001; Saraswati et al. 2004; Fontanier et al. 2006; Schmiedl and Mackensen 2006; Hoogakker et al. 2010; Ishimura et al. 2012; Marchitto et al. 2014). Some species of benthic foraminifera prefer to live within the uppermost centimetre of sediments (epifaunal), some within the top two centimetres (shallow infaunal) and some below two centimetres of sediments (deep infaunal) (Corliss 1991; Jorissen et al. 1995). Differences in their habitation as well as their generic divisions cause disequilibria in isotopic fractionation within their biogenic calcitic tests with respect to sea water (Rathburn et al. 1996; Fontanier et al. 2006; Hoogakker et al. 2010; Ishimura et al. 2012). This disequilibrium in isotopic fractionation in benthic foraminifera is mainly controlled by the kinetic and metabolic effects, pore water chemistry, food supply and $\mathrm{pH}$ of the sea/pore waters (McConnaughey 1989; Cooke and Rohling 2001; Fontanier et al. 2006; Hoogakker et al. 2010; Ishimura et al. 2012).

Numerous studies have been undertaken for the interspecies conversion of isotopic values by adding or subtracting vital offsets (Shackleton 1974; Graham et al. 1981; Katz et al. 2003; Fontanier et al. 2006; Mackensen 2008; Ishimura et al. 2012; Marchitto et al. 2014). This conversion is known as standardization of isotopic values of one species with respect to another. Standardization is required when a selected species for isotopic analysis does not continuously show down core abundance. In such a case, isotopic analysis of two or more other species are required and need standardization with respect to the earlier selected species. Such standardization of isotopic values with sea water or other species will give us a continuous down core isotopic record and help us to infer palaeoceanography and pore water chemistry. In this way, the isotopic values of Cibicides wuellerstorfi, Oridorsalis umbonatus and Uvigerina peregrina are commonly used in palaeoclimate study (Shackleton 1974; Woodruff et al. 1980; Bemis et al. 1998; Haug and Tiedemann 1998; Fontanier et al. 2006; Hoogakker et al. 2010; Bhaumik et al. 2011).

The present study is pursued on the carbon and oxygen stable isotopic values of paired species Bulimina marginata-Cibicides wuellerstorfi, Ammonia spp.-Loxostomum amygdalaeformis (from NGHP-Hole 10D, Krishna-Godavari Basin, Bay of Bengal) and Bolivina seminuda-Nonionella auris (from ODP Hole 680B, Peru offshore margin) to estimate isotopic offset (vital effect) as well as isotopic adjustment (standardisation) of paired species. Furthermore, comparison among the paired species isotopic values taken from the same downcore samples will enable to infer the microhabitat preference of one species with respect to the other. 


\section{Location and oceanographic settings}

National Gas Hydrate Program (NGHP) Site-10D $\left(15^{\circ} 51.8609^{\prime} \mathrm{N}, 81^{\circ} 50.0749^{\prime} \mathrm{E}\right.$; water depth $\left.1038 \mathrm{~m}\right)$ is located $\sim 36 \mathrm{~km}$ off the eastern coast of India in the Krishna-Godavari $(\mathrm{K}-\mathrm{G})$ Basin within the Bay of Bengal, Indian Ocean (Collett et al. 2007, figure 1). A total of 97 core samples were analysed from $200 \mathrm{~m}$ long core of Quaternary age. Seismic study together with pore water salinity and core sediment observations showed that this site has maximum gas hydrate saturation between 27 and $160 \mathrm{~m}$ below sea floor (mbsf) (Collett et al. 2007).

The east Indian coastal current (EICC) flows along the eastern coast of India flooding up to a depth of $\sim 300 \mathrm{~m}$ (Mukherjee et al. 2014). The mid-to-deep water column of the Indian Ocean can be divided vertically into a number of water masses; the Antarctic Intermediate Water (AAIW) up to $\sim 1200 \mathrm{~m}$ (Tchernia 1980), a mixture of well oxygenated North Atlantic Deep Water (NADW) and North Indian Deep Water or NIDW between 1200 and $2000 \mathrm{~m}$ (Wyrtki 1971; Tchernia 1980; GEOSECS 1983; Bhaumik et al. 2014) and the Antarctic Bottom Water (AABW), which is cold, nutrient-rich and lies below $3000 \mathrm{~m}$ (Tchernia 1980;
Bhaumik et al. 2014). The water mass between 2000 and $3000 \mathrm{~m}$ is a mixture of NADW and AABW (De and Gupta 2010; Bhaumik et al. 2014).

Ocean Drilling Program (ODP) Hole 680B, Leg $112\left(11^{\circ} 03.90^{\prime} \mathrm{S}, 78^{\circ} 04.67^{\prime} \mathrm{W}\right.$, water depth $\left.252.5 \mathrm{~m}\right)$ is located in the Salaverry Basin, off Peru continental margin of the east Pacific Ocean (Suess et al. 1988; figure 2). A total of 300 samples (late Pliocene to Recent) were analysed, out of which only 119 samples are productive in terms of foraminiferal population. The Peru continental margin or Andean continental margin is configured by both tectonic activity and coastal upwelling (Suess et al. 1988). The Peru Current and the Peru Counter Current are the two oceanic currents that dominate over the studied site (Suess et al. 1988; Oberhänsli et al. 1990). The Peru continental margin represents one of the best coastal upwelling regimes in the world and is rich in organic carbon (Suess et al. 1988).

\section{Datasets and methods}

Foraminiferal separation from the core samples was carried out following the technique described

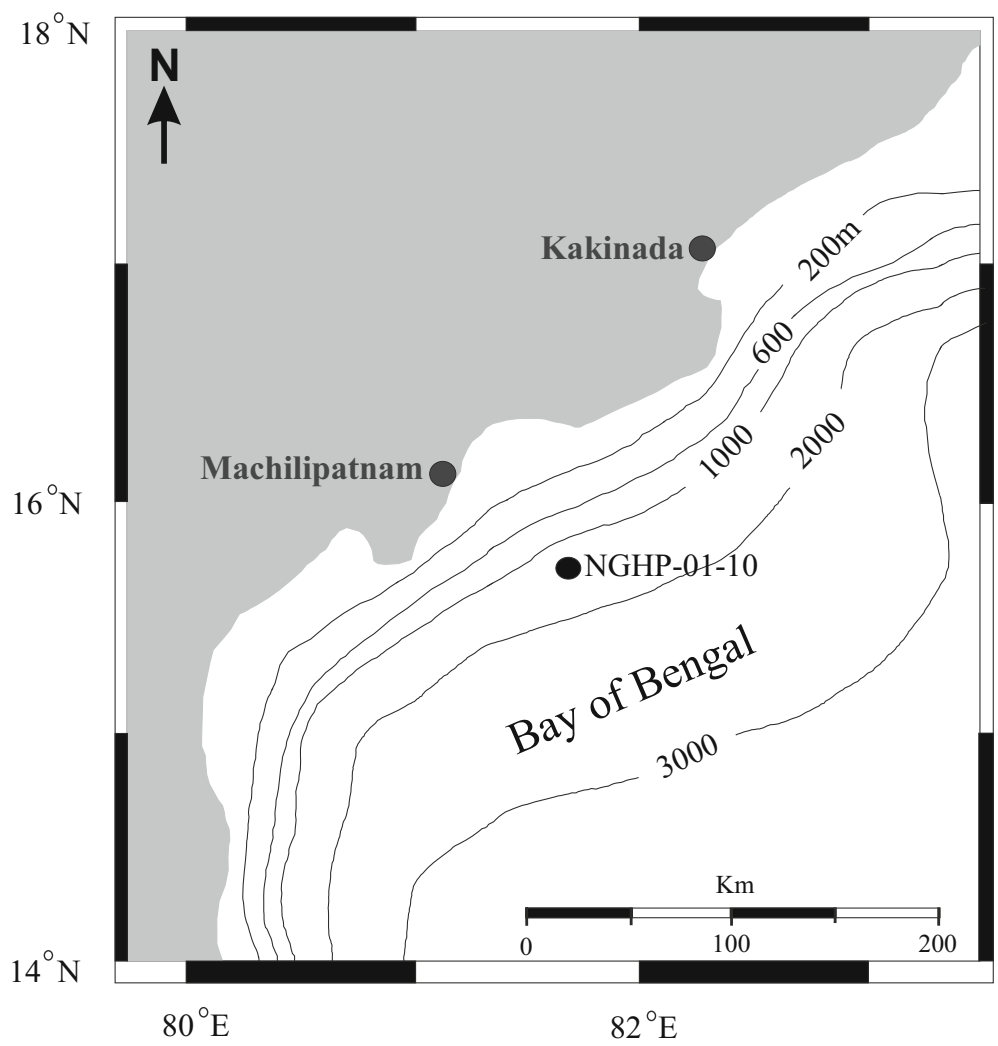

Figure 1. Location map of NGHP Hole 10D in the Krishna-Godavari Basin, Bay of Bengal (modified from Collett et al. 2007). 


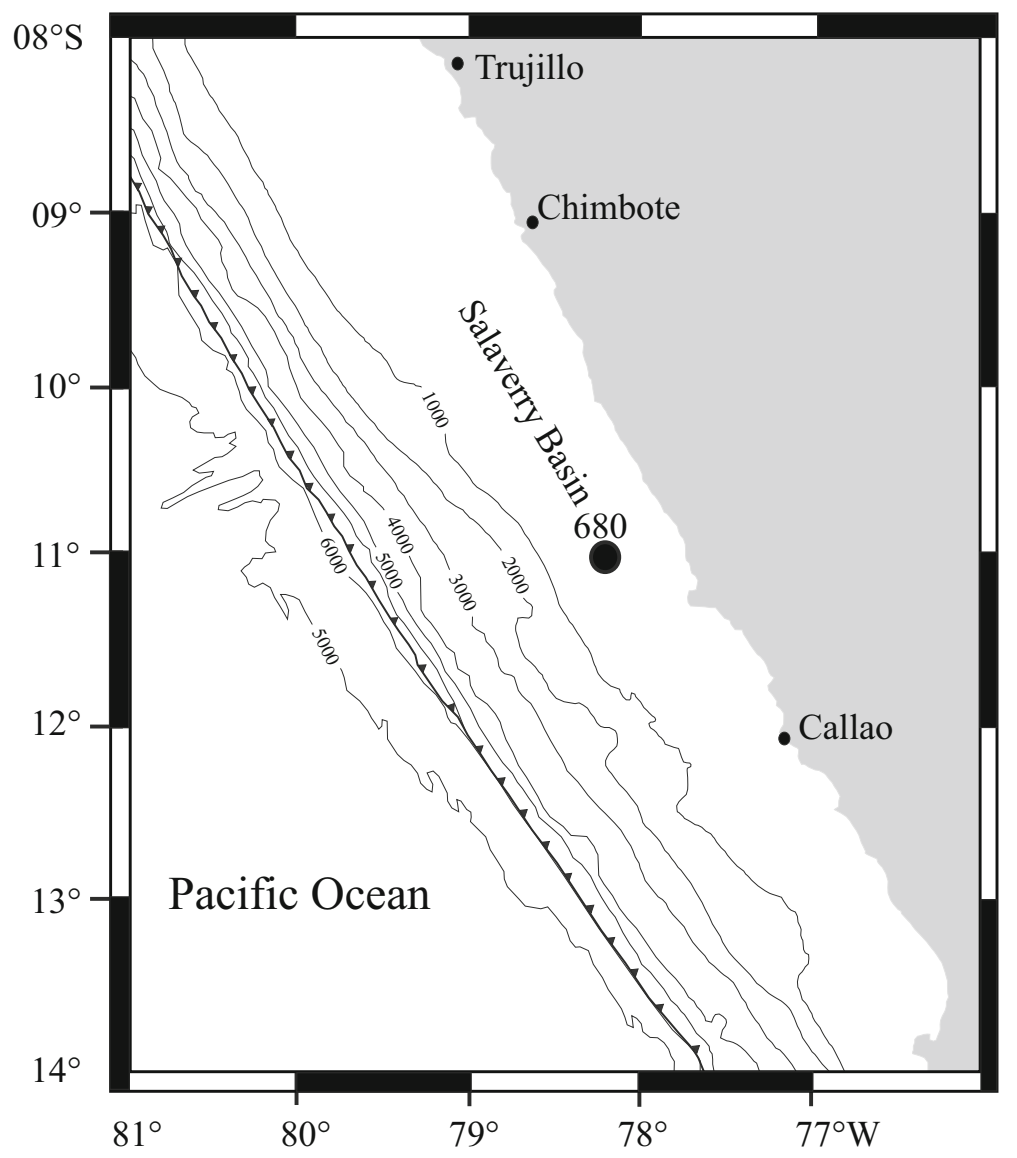

Figure 2. Location map of ODP Hole 680B, offshore Peru (Suess et al. 1988).

in Bhaumik et al. (2011). Specimens of benthic foraminiferal species Cibicides wuellerstorfi, Bulimina marginata, Ammonia spp. (including A. beccarii, A. tepida, A. perkinsoniana and two other unidentified forms resembling Ammonia) and Loxostomum amygdalaeformis were taken from fraction range between 125 and $300 \mu \mathrm{m}$ from NGHP Hole 10D, K-G Basin (figure 3). Specimens of Ammonia beccarii are considered as primary species for isotopic analysis to minimise possibility of inter species variation within Ammonia group. However few specimens of other species of Ammonia (A. tepida, A. perkinsoniana) were also picked in some cases to achieve minimum requirement of specimens for isotopic analysis. None of the specimens contain any earthy colour or polished or abrasion/worn out indicating no signature of transportation or reworking. At least eight specimens of each species were picked for isotopic analysis and cleaned in an ultrasonic bath using methanol. All the required species ( $C$. wuellerstorfi, B. marginata, Ammonia spp. and L. amygdalaeformis) are not documented in each down core samples. Specimens of different species were picked based on their availability in each down core sam- ples. In this way specimens of $B$. marginata and C. wuellerstorfi show their coexistence only in 10 down-core samples (Appendix) out of total 97 samples. Similarly 19 down-core samples documented coexistence of Ammonia spp. and L. amygdalaeformis (Appendix).

Approximately 30 specimens of Bolivina seminuda and 18 specimens of Nonionella auris were picked from the same fraction size (between 125 and $300 \mu \mathrm{m}$ ) from ODP Hole 680B, Peru offshore (figure 3). Coexistence of these species with significant numbers for isotopic analysis are observed only in 27 down-core samples (Appendix). All the specimens were ultrasonically cleaned with methanol prior to isotopic analysis. No transported/reworked specimens were used for isotopic analysis.

Stable carbon and oxygen isotopic analyses of benthic species from the $\mathrm{K}-\mathrm{G}$ Basin were carried out at the Mass Spectrometry Laboratory of the Indian Institute of Technology, Kharagpur. Isotopic compositions of foraminiferal carbonates were measured using a continuous flow Delta ${ }^{\text {PLUS }} \mathrm{XP}$ stable isotope ratio mass spectrometer equipped with an automated carbonate preparation system 


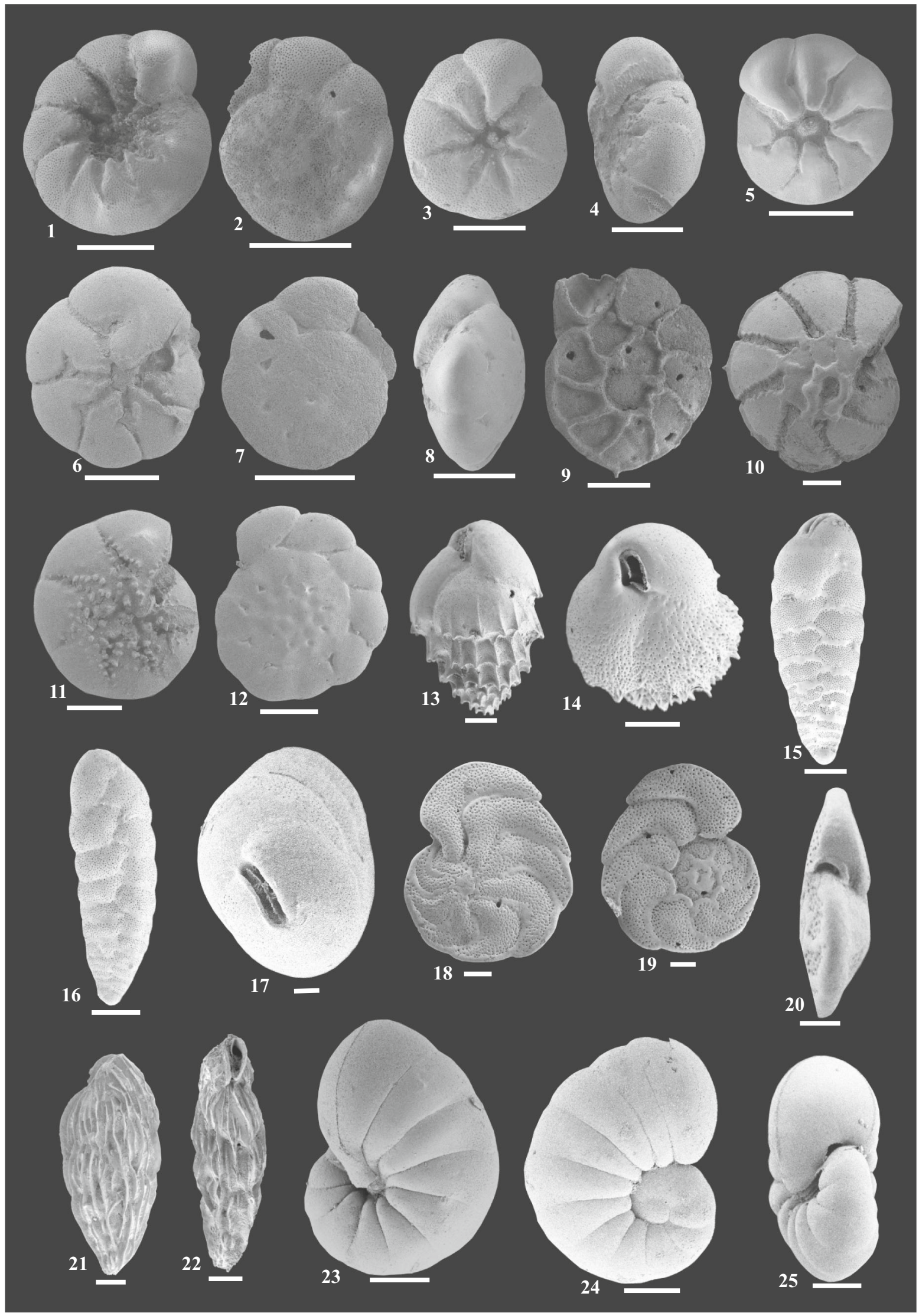

Figure 3. SEM images of foraminiferal species used for isotopic analysis. Bars represent $100 \mu \mathrm{m}$ size. 1-2: Ammonia beccarii, 3-4: Ammonia perkinsoniana, 5-8: Ammonia tepida, 9-12: Ammonia spp., 13-14: Bulimina marginata, 15-17: Bolivina seminuda, 18-20: Cibicides wuellerstorfi, 21-22: Loxostomum amygdalaeformis, 23-25: Nonionella auris. 
(Gas-Bench-II). Around $200 \mu \mathrm{g}$ sample was transferred into glass vials and flushed with $99.999 \%$ pure $\mathrm{He}$ gas. Samples were reacted with $100 \%$ $\mathrm{H}_{3} \mathrm{PO}_{4}$ at $72^{\circ} \mathrm{C}$. The released $\mathrm{CO}_{2}$ was purified by removing water and other trace gases and isotopic ratios were measured. A routine precision of $\pm 0.1 \%$ by analysing two in-house $\mathrm{CaCO}_{3}$ standards as Z-Carrara (procured from Physical Research Laboratory, Ahmedabad) and BDH (procured from University College London) calibrated against NBS-19.

Samples from the Peru offshore zone were analysed in a Stable Isotope Ratio Mass Spectrometer (Delta V plus model from Thermo Fisher) at the Wadia Institute of Himalayan Geology, Dehradun, following the same procedure as described above. For day-to-day measurement, secondary laboratory standards were used which were calibrated against NBS-18. Repeat measurements of the secondary laboratory standards show a precision and accuracy better than $\sim 0.1 \%$ (1SD) for carbon and oxygen isotope measurements. All isotopic results from both the sites are expressed in terms of parts per mille $(\%)$ normalised to VPDB standards.

The ordinary least-squared (OLS) regression method was performed to estimate the isotopic offsets between each paired species. The OLS regression method is applied on the isotopic datasets to estimate the true population relationship between a continuous response variable $(y)$ and a continuous explanatory variable $(x)$ as the datasets are small and lie within control limits. A similar study has earlier been carried out by Katz et al. (2003) on isotopic values of some early Palaeogene benthic foraminifera. Katz et al. (2003) used the least median of squares (LMS) based on the method of moment (MM) estimator because they used large datasets in their study.

The OLS regression is a generalised linear modelling technique that is used to model a single response variable which has been recorded on at least an interval scale. At a very basic level, the relationship between a continuous response variable $(y)$ and a continuous explanatory variable $(x)$ may be represented using a line of best-fit, where $y$ is predicted, at least to some extent, by $x$ (Ryan 1997).

\section{Results}

In case of the species pair $C$. wuellerstorfi-B. marginata, both the carbon and oxygen isotopes show reasonably positive correlation $(R=0.57$ and $R=0.64$, respectively) with relatively low p-values (figure 4 , table 1 ). Reasonably positive correlation $(R=0.60)$ with significant low pvalues $(\mathrm{p}=0.007)$ for $\delta^{13} \mathrm{C}$ is observed in the pair Ammonia spp.-L. amygdalaeformis (figure 4, table 1$)$. But the $\delta^{18} \mathrm{O}$ values for the same pair do not show good correlation (figure 4, table 1). A good correlation $(R=0.76)$ with very low $\mathrm{p}$ value is also observed for $\delta^{13} \mathrm{C}$ of the species pair $B$. seminuda-N. auris, but the same pair does not show good correlation $(R=0.17)$ for $\delta^{18} \mathrm{O}$ (figure 4 , table 1 ).

The downcore variations of isotope data for all the above-mentioned paired species ( $C$. wuellerstorfi-B. marginata, Ammonia spp. - L. amygdalaeformis and $B$. seminuda-N. auris) are also considered for comparison (figure 5). Cibicides wuellerstorfi reliably records $\delta^{13} \mathrm{C}$ of dissolved inorganic carbon in sea water as it precipitates its test close to the oxygen isotopic equilibrium of sea water with a constant offset of $0.64 \%$ (Shackleton et al. 1984; Cooke and Rohling 2001; Katz et al. 2003). Thus addition of $0.64 \%$ with the $\delta^{18} \mathrm{O}$ values of $C$. Wuellerstorfi (i.e., adjusted values) gives the oxygen isotopic values of sea water (figure 5). However specimens of $C$. wuellerstorfi is not recorded at Hole 680B.

Derived equations obtained by the OLS regression methods are presented with $R$ and p-values in table 1 for the prediction of estimated isotopic offsets of the paired species. The table exhibits the degree of percentage variations of data for the pairs $C$. wuellerstorfi-B. marginata (for $\delta^{13} \mathrm{C}$ and $\delta^{18} \mathrm{O}$ ), Ammonia spp. - L. amygdalaeformis (only for ${ }^{13} \mathrm{C}$ ), and $B$. seminuda-N. auris (only for ${ }^{13} \mathrm{C}$ ) are $>55 \%$. The p-values for all the above cases show that the paired datasets are statistically significant at $90 \%$ confidence interval. The derived OLS regression equations for the paired species $\delta^{18} \mathrm{O}_{\text {Ammonia spp. }}-\delta^{18} \mathrm{O}_{\text {L. amygdalaeformis }}$ and $\delta^{18} \mathrm{O}_{B}$. seminuda $-\delta^{18} \mathrm{O}_{N}$. auris show less percentage variation of data with high p-values.

\section{Discussion}

\subsection{Factors for fractionation of foraminiferal carbon and oxygen isotopes}

Isotopic analyses of each paired species were performed on specimens picked from the same sediment samples (same depth for each pair of data). Thus it is presumed that the effect of climate variability, bottom and pore water temperatures, pore 

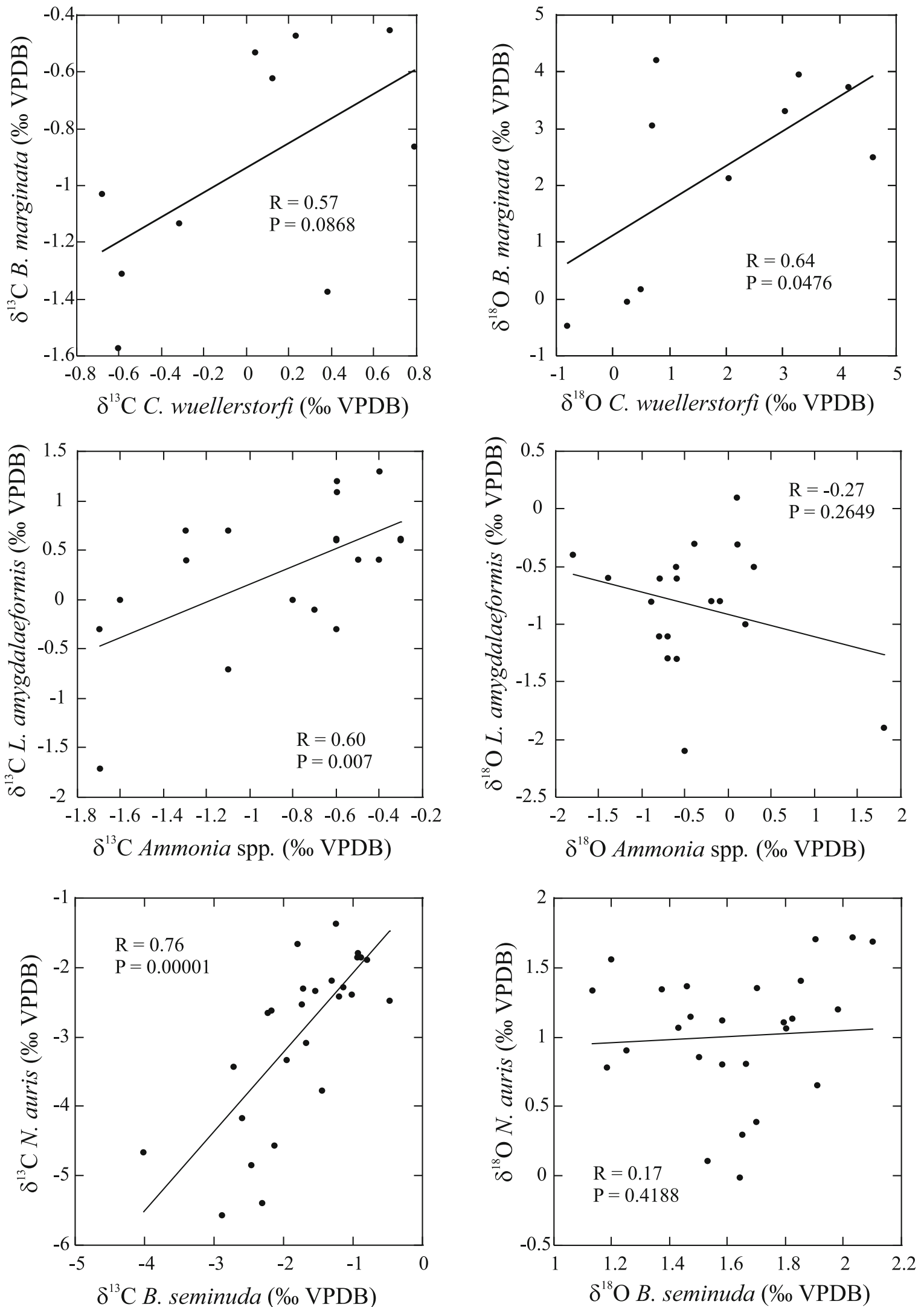

Figure 4. Scatter plots of isotopic values for the paired species Cibicides wuellerstorfi-Bulimina marginata, Ammonia spp.Loxostomum amygdalaeformis and Bolivina seminuda-Nonionella auris. Correlation and p-values are given within each panel for every pair. Scatter $\delta^{18} \mathrm{O}$ plots of Ammonia spp.-Loxostomum amygdalaeformis and Bolivina seminuda-Nonionella auris do not show significant correlation and hence are not considered for OLS regression analysis. 
Table 1. Equations with dependent and independent variables as derived by OLS regression analysis.

\begin{tabular}{lllcccc}
\hline \multicolumn{1}{c}{ Variable $(y)$} & \multicolumn{1}{c}{ Variable $(x)$} & $N$ & $\begin{array}{c}\text { Regression } \\
\text { equation } y \text { on } x\end{array}$ & Regression \\
equation $x$ on $y$ & $R$ & $\mathrm{p}$-value \\
\hline$\delta^{13} \mathrm{C}$ C. wuellerstorfi & $\delta^{13} \mathrm{C}$ B. marginata & 10 & $y=0.75 \mathrm{x}+0.7$ & $x=0.43 \mathrm{Y}-0.94$ & 0.57 & 0.0868 \\
$\delta^{18} \mathrm{O}$ C. wuellerstorfi & $\delta^{18} \mathrm{O}$ B. marginata & 10 & $y=0.66 \mathrm{x}-0.29$ & $x=0.61 \mathrm{Y}+1.5$ & 0.64 & 0.0476 \\
$\delta^{13} \mathrm{C}$ Ammonia spp. & $\delta^{13} \mathrm{C}$ L. amygdalaeformis & 19 & $y=0.39 \mathrm{x}-0.96$ & $x=0.91 \mathrm{Y}+1.1$ & 0.60 & 0.007 \\
$\delta^{13} \mathrm{C}$ B. seminuda & $\delta^{13} \mathrm{C}$ N. auris & 26 & $y=0.5 \mathrm{x}-0.25$ & $\mathrm{x}=1.1 x-1.2$ & 0.76 & 0.000 \\
\hline
\end{tabular}

$\overline{R \text { and } \mathrm{p} \text {-values are included in the table to understand statistical significance of the dataset. The first regression equation }}$ predicted the value of $y$ when $x$ is known and the second regression equation predicted the value of $x$ when $y$ is known.

water chemistry, $\mathrm{pH}$ of water and diagenesis will be equally effective for both the paired species picked from single depth. Variations in microhabitat (epifaunal, infaunal and deep infaunal), ontogeny and respiration effects are considered as important factors influencing the fractionation of isotopes of each paired species (Cooke and Rohling 2001; Ishimura et al. 2012). Studies showed that ontogenic effect is more intense during juvenile stages (Moberly 1968; Berger et al. 1978). Relatively larger size fraction $(125-300 \mu \mathrm{m})$ bearing adult forms are used in this study. Thus it may be assumed that ontogenic effect is minimum in used specimens.

Fractionation of carbon isotope in benthic foraminiferal calcitic test mainly depends on the food habits and microhabitat within the sediments (Fontanier et al. 2006; Mackensen 2008). It is already suggested that decomposition of sedimentary organic matter along the down core is responsible for the depletion in $\delta^{13} \mathrm{C}$ within pore water. This isotopic depletion is reflected by the infaunal to deep-infaunal benthic foraminifera calcified in pore water (Fontanier et al. 2006; Mackensen 2008). However, the epifaunal taxa reflect the bottom water isotopic composition and calcified in equilibrium with the ocean water (Bemis et al. 1998; Fontanier et al. 2006). Thus richness of organic carbon within the sediments and its intake by foraminifera is mirrored by the carbon isotopic fractionation. $\mathrm{CO}_{2}$ and dissolved inorganic carbonate (DIC) within cell of foraminifera produced during metabolism are used for test calcification and thus shows a direct relation in fractionation of carbon isotopes (de Nooijer et al. 2009).

There are two school of thoughts regarding the biasness of $\delta^{13} \mathrm{C}$ in foraminiferal calcitic test in methane rich environment. One group of workers suggests that presence of methane may cause depletion in foraminiferal $\delta^{13} \mathrm{C}$ in a tune of -5 to $-55^{\circ}$ o (Hill et al. 2003, 2004; Barbieri and Panieri 2004;
Martin et al. 2007) whereas others proposed foraminiferal distribution as well as foraminiferal carbon isotopes are unbiased by the methane seepages (Torres et al. 2003; Lobegeier and Sen Gupta 2008). None of the specimens used in this study bears such depleted $\delta^{13} \mathrm{C}$ values and thus it may be considered that the faunal assemblages are unaffected by methane seepage. Studies showed that shallow infaunal to deep infaunal species generally bear depleted $\delta^{13} \mathrm{C}$ values at the tune of -2 to $-4 \%$ (Ravelo and Hillaire-Marcel 2007; Mackensen 2008).

On the other hand, fractionation of oxygen isotope in foraminiferal calcitic test depends on numerous factors such as kinetic effect (temperature dependent), ontogenesis, symbiosis, photosynthesis, respiration, gametogenesis and change in pH (Lane and Doyle 1956; Grossman 1987; Wefer and Berger 1991; Spero and Lea 1996; Hoogakker et al. 2010; Ishimura et al. 2012; Marchitto et al. 2014). Studies showed that $\delta^{18} \mathrm{O}$ enrichment in calcitic tests of benthic foraminifera is also directly linked to the depth preference owing to the kinetic effect (Bemis et al. 1998; Hoogakker et al. 2010; Marchitto et al. 2014).

\subsection{Microhabitats of paired species}

\subsubsection{Paired Cibicides wuellerstorfi-Bulimina marginata}

Bulimina marginata has been reported from surface samples of the North Sea (Jarke 1961; Gabel 1971), whereas some workers inferred that these species prefer to live within the top $1 \mathrm{~cm}$ of sediments (Stefanelli et al. 2005; Murray 2006; Basak et al. 2009). Study of Brückner and Mackensen (2008) showed that low mean $\delta^{13} \mathrm{C}$ values of $B$. marginata reflect a shallow infaunal habitat of this species. Carbon isotopic distribution pattern of both the species ( $C$. wuellerstorfi-B. marginata) in the present study shows almost 
parallelbreak relationship throughout the studied interval with lighter $\delta^{13} \mathrm{C}$ values of $B$. marginata (figure 5). Lighter $\delta{ }^{13} \mathrm{C}$ values of $B$. marginata than $C$. wuellerstorfi (figure 5), thus indicate infaunal habitat in organic carbon rich environment. The depletion in $\delta^{13} \mathrm{C}$ of $B$. marginata could be explained by release of ${ }^{13} \mathrm{C}$ depleted $\mathrm{CO}_{2}$ owing to high anaerobic remineralisation rate of organic materials at depth (Cooke and Rohling 2001; Fontanier et al. 2006; Hoogakker et al. 2010). The released ${ }^{13} \mathrm{C}$ depleted $\mathrm{CO}_{2}$ then used to build calcitic tests of this species (de Nooijer et al. 2009) which in-turn is documented by lighter $\delta^{13} \mathrm{C}$ values.

Seven out of ten $\delta^{18} \mathrm{O}$ values of $B$. marginata show very close relationship with adjusted $\delta^{18} \mathrm{O}$ values of $C$. wuellerstorfi (equilibrated with sea water). The small deviations in $\delta^{18} \mathrm{O}$ indicate that $B$. marginata calcified its test almost in equilibrium with the sea water (figure 5 ). However, the deviations in $\delta^{18} \mathrm{O}$ are more when compared with unadjusted oxygen isotopic values of $C$. wuellerstorfi. This enrichment in $\delta^{18} \mathrm{O}$ of $B$. marginata is also indicative of infaunal habitat. Bemis et al. (1998) observed mild $\delta^{18} \mathrm{O}$ enrichment in infaunal Uvigerina than epifaunal Cibicidoides owing to low pore-water $\mathrm{pH}$ and decreased $\mathrm{CO}_{3}{ }^{2-}$ in deeper sediments. Study of Spero et al. (1997) also inferred that $\delta^{18} \mathrm{O}$ in foraminiferal carbonate decreases with increasing $\mathrm{CO}_{3}{ }^{2-}$.

\subsubsection{Paired Ammonia spp.-Loxostomum amygdalaeformis}

Studies showed that Ammonia group of species prefer infaunal microhabitat (Debenay et al. 1998; Murray 2006). On the other hand habitat preference of $L$. amygdalaeformis is not well established. However, shape of these species reflects shallow infaunal habitat (Bernhard et al. 1997; Hottinger 2000). Comparison between carbon isotopic plot of Ammonia spp. and L. amygdalaeformis shows significant difference in their $\delta^{13} \mathrm{C}$ values (figure 5). Depleted carbon isotopic values of Ammonia spp. as compared to L. amygdalaeformis thus clearly indicate its infaunal habitat (preference to greater depth). This depletion in $\delta^{13} \mathrm{C}$ of Ammonia may be related to high anaerobic remineralisation rate of organic materials as well as utilisation of released $\mathrm{CO}_{2}$ to build calcitic tests as stated in case of pair C. wuellerstorfi- B. marginata.

A comparison of oxygen isotope values of both the species reveals that $\delta^{18} \mathrm{O}$ of Ammonia shows enrichment in 11 points, depletion in 3 points and bears almost similar values in 5 points (figure 5 ). Thus oxygen isotope values do not provide a clear picture about the difference in their microhabitat.

\subsubsection{Paired Bolivina seminuda and Nonionella auris}

In general, B. seminuda is considered as an epifaunal to shallow infaunal species (Gooday et al. 2000; Duijnstee 2001) whereas $N$. auris is considered to be deep-infaunal (Corliss and Emerson 1990; Wefer et al. 1994). Continuous $\delta^{13} \mathrm{C}$ plot of $N$. auris and B. seminuda shows that $N$. auris always bear lighter $\delta^{13} \mathrm{C}$ values than $B$. seminuda within the sequence (figure 5). Depletion in $\delta^{13} \mathrm{C}$ thus indicates deep-infaunal habitat of $N$. auris than $B$. seminuda which supports the observations of earlier researchers who assigned deep infaunal habitat to $N$. auris (Corliss and Emerson 1990; Wefer et al. 1994). As stated earlier, depletion in $\delta^{13} \mathrm{C}$ of $N$. auris could be related to release ${ }^{13} \mathrm{C}$ depleted $\mathrm{CO}_{2}$ owing to anaerobic remineralisation of organic matter (Cooke and Rohling 2001; Fontanier et al. 2006; Hoogakker et al. 2010) and intake of these $\mathrm{CO}_{2}$ to build the test of this species (de Nooijer et al. 2009).

Previous works and this study show that $N$. auris prefers more depth (deep infaunal) than $B$. seminuda (Corliss and Emerson 1990; Wefer et al. 1994; Gooday et al. 2000; Duijnstee 2001). Studies also showed that enrichment in $\delta^{18} \mathrm{O}$ of benthic foraminiferal tests increases with depth owing to the change in kinetic effect (Bemis et al. 1998; Hoogakker et al. 2010; Marchitto et al. 2014). Thus it is expected that infaunal $N$. auris should bear enriched $\delta^{18} \mathrm{O}$ values than $B$. seminuda. However, comparison in $\delta^{18} \mathrm{O}$ values of $N$. auris with respect to $B$. seminuda shows depletion instead of enrichment in most of the depth points (figure 5). Thus, the depletion in $\delta^{18} \mathrm{O}$ of $N$. auris with respect to $B$. seminuda is unexpected and does not relate to its microhabitat preference. Rather it may be linked to preference of food and oxygen. $N$. auris prefers to live in high organic flux environment (Wefer et al. 1994; Rathburn et al. 2000) than B. seminuda, the latter is more influenced by oxygen (Sen Gupta and Machain-Castillo 1993). Thus it may be presumed that larger body volume bearing $N$. auris requires more utilisation of food to maintain metabolic activity and produced isotopically lighter oxygen $\left({ }^{16} \mathrm{O}\right)$ bearing more $\mathrm{CO}_{2}$ as a byproduct of metabolism. This generated metabolic 

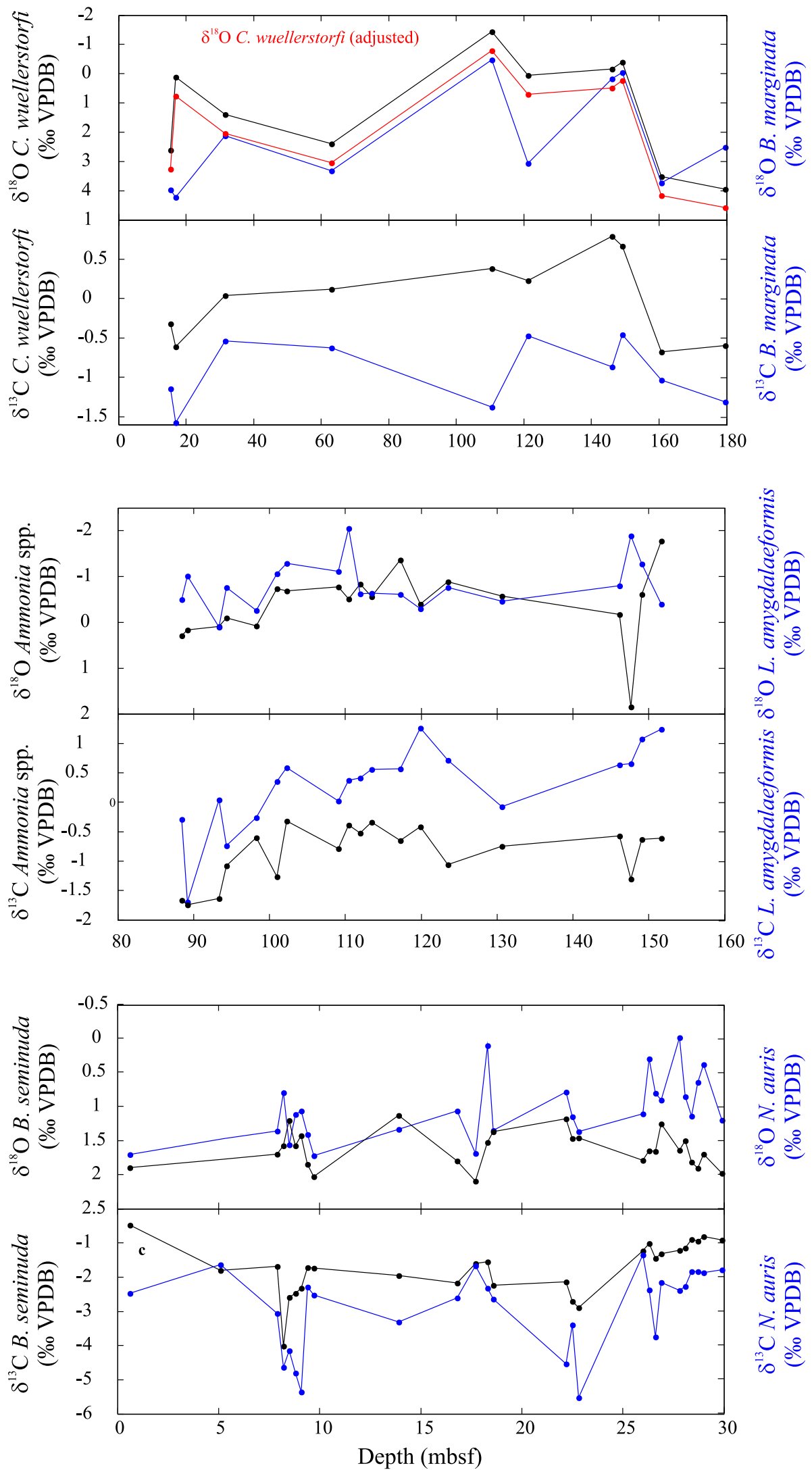

Figure 5. Comparison in continuous plots of carbon and oxygen isotopic values for the paired species Cibicides wuellerstorfiBulimina marginata, Ammonia spp.-Loxostomum amygdalaeformis and Bolivina seminuda-Nonionella auris. Plots of adjusted $\delta^{18} \mathrm{O}$ of $C$. wuellerstorfi to sea water is presented by red colour. 
Table 2. Isotopic correction factors for paired species.

\begin{tabular}{lc}
$\begin{array}{l}\text { Correction factors when } \\
y \text { is dependent variable }\end{array}$ & $\begin{array}{c}\text { Correction factors when } x \\
\text { is dependent variable }\end{array}$ \\
\hline$\delta^{13} \mathrm{C}$ of $\mathrm{Bm}=\delta^{13} \mathrm{C}$ of $\left.\mathrm{Cw}-0.7\right) / 0.75$ & $\delta^{13} \mathrm{C}$ of $\mathrm{Cw}=\left(\delta^{13} \mathrm{C}\right.$ of $\left.\mathrm{Bm}+0.94\right) / 0.43$ \\
$\delta^{18} \mathrm{O}$ of $\mathrm{Bm}=\left(\delta^{18} \mathrm{O}\right.$ of $\left.\mathrm{Cw}+0.29\right) / 0.66$ & $\delta^{18} \mathrm{O}$ of $\mathrm{Cw}=\left(\delta^{18} \mathrm{O}\right.$ of $\left.\mathrm{Bm}-1.5\right) / 0.61$ \\
$\delta^{13} \mathrm{C}$ of $\mathrm{La}=\delta^{13} \mathrm{C}$ of $\left.\mathrm{Am}+0.96\right) / 0.39$ & $\delta^{13} \mathrm{C}$ of $\mathrm{Ab}=\left(\delta^{13} \mathrm{C}\right.$ of $\left.\mathrm{La}-1.1\right) / 0.91$ \\
$\delta^{13} \mathrm{C}$ of $\mathrm{Na}=\left(\delta^{13} \mathrm{C}\right.$ of $\left.\mathrm{Bs}+0.25\right) / 0.5$ & $\delta^{13} \mathrm{C}$ of $\mathrm{Bs}=\left(\delta^{13} \mathrm{C}\right.$ of $\left.\mathrm{Na}+1.2\right) / 1.1$ \\
\hline It is important to note that equation for conversion of isotopic values of one species to other species \\
and vice versa are different as regression coefficients are different. La = L. amygdalaeformis, Am $=$ \\
Ammonia spp., Bm $=$ B. marginata, $\mathrm{Cw}=C$. wuellerstorfi, $\mathrm{Na}=N$. auris and Bs $=$ B. seminuda.
\end{tabular}

$\mathrm{CO}_{2}$ with internal DIC pool together might be used to build the test of $N$. auris (Lane and Doyle 1956; Grossman 1987; de Nooijer et al. 2009). Thus the utilisation of isotopically lighter oxygen and carbon isotopes together leads to the depletion in $\delta^{18} \mathrm{O}$ as well as $\delta^{13} \mathrm{C}$ in the test of $N$. auris.

\subsection{Interspecies isotopic correction factors (vital effects)}

It is considered that the isotopic offset of a species with respect to equilibrium or other species is constant through time (Shackleton 1974; Woodruff et al. 1980; Marchitto et al. 2014). Each and every species has its own preferred microhabitat, ontogeny, and respiration rate which probably deviates the fractionation of isotopes from equilibrium (Cooke and Rohling 2001). Isotopic values of species like Cibicides wuellerstorfi, Oridorsalis umbonatus and Uvigerina peregrina are widely used for palaeoceanographic reconstruction. Paucity of some of these species forced us to determine the isotopic values of other species for palaeoceanographic reconstruction, and hence there is a need to estimate isotopic offset of other species with some known species for better understanding of palaeoceanography. OLS regression study is pursued on both $\delta^{13} \mathrm{C}$ and $\delta^{18} \mathrm{O}$ values of paired species $C$. wuellerstorfi-B. marginata and the correction factors are presented in table 2. However, the OLS regression study is only pursued on $\delta^{13} \mathrm{C}$ data of pair species Ammonia spp.-L. amygdalaeformis and $B$. seminuda-N. auris and related correction factors are tabulated in table 2 . The OLS regression study is not performed on other cases as the correlation values are low.

This study shows difference in oxygen isotopic correction factor from the estimation of Katz et al. (2003) for the pair species C. wuellerstorfi-B. marginata (table 2). Katz et al. (2003) show an adjustment relationship for oxygen isotope as $\delta^{18} \mathrm{O}$ of Bulimina spp. $-0.28=\delta^{18} \mathrm{O}$ Cibicidoides spp. whereas present data show the factor as $\left(\delta^{18} \mathrm{O}\right.$ of B. marginata-1.5)/0.61 $=\delta^{18} \mathrm{O}$ C. wuellerstorfi. This study is performed on relatively less number of samples $(N=10)$ and thus scope of further investigation still exists. This study also suggests that test calcification of $B$. marginata is almost in equilibrium with sea water as observed by Shackleton et al. (1984) whereas other species considered in this study do not show such equilibrium with sea water.

\section{Conclusions}

Study from the Krishna-Godavari Basin and offshore Peru shows that benthic foraminiferal species Bulimina marginata, Ammonia spp., and Nonionella auris prefer greater depth (infaunal) whereas Cibicides wuellerstorfi, is raised epifaunal, and Loxostomum amygdalaeformis and Bolivina semin$u d a$ are epifaunal to shallow infaunal in nature. Fractionation of carbon isotope in these foraminiferal tests is related to depth of microhabitat as well as incorporation of ${ }^{13} \mathrm{C}$ depleted $\mathrm{CO}_{2}$ released by anaerobic remineralisation of organic materials. However, oxygen isotope fractionation shows direct relation with depth preference for the pair species C. wuellerstorfi-B. marginata. Depleted $\delta^{18} \mathrm{O}$ of $N$. auris (infaunal) indicates more utilisation of metabolic $\mathrm{CO}_{2}$ to build test of $N$. auris.

Estimated isotopic correction factors obtained from the OLS regression methods for the species pairs $\left(\delta^{13} \mathrm{C}\right.$ and $\delta^{18} \mathrm{O}$ of $C$. wuellerstorfi-B. marginata, $\delta^{13} \mathrm{C}$ of $L$. amygdalaeformis-Ammonia spp., $N$. auris - B. seminuda) are statistically reliable as the degree of percentage variations of data are $>55 \%$. The p-values for these paired datasets are also statistically significant at $90 \%$ confidence level and thus may be used as isotopic correction factors within the upper bathyal zone. 


\section{Acknowledgements}

The authors thankfully acknowledge all the reviewers for their scientific suggestions. The research is financially supported by DST Research Project [SR/S4/ES-542/2010(G)] and MoES Research Project [No: MoES/P.O.(Geosci)/24/2014]. AKB is thankful to Prof. A Sarkar, Indian Institute of Technology, Kharagpur and Dr Santosh K Rai, Wadia Institute of Himalayan Geology, Dehradun, for providing the isotope analyses facilities. AKB is also thankful to NGHP and IODP for providing core samples for this study. AKG thanks DST for funding under J.C. Bose fellowship.

\section{Appendix}

Table A1. Carbon and oxygen isotope dataset with sample depth used in this study.

\begin{tabular}{|c|c|c|c|c|}
\hline $\begin{array}{l}\text { Depth } \\
\text { (mbsf) }\end{array}$ & $\begin{array}{c}\delta^{13} \mathrm{C} \\
\text { C. wuellerstorfi }\end{array}$ & $\begin{array}{c}\delta^{13} \mathrm{C} \\
\text { B. marginata }\end{array}$ & $\begin{array}{c}\delta^{18} \mathrm{O} \\
\text { C. wuellerstorfi }\end{array}$ & $\begin{array}{c}\delta^{18} \mathrm{O} \\
\text { B. marginata }\end{array}$ \\
\hline 15.36 & -0.32 & -1.13 & 2.62 & 3.97 \\
\hline 16.86 & -0.61 & -1.57 & 0.12 & 4.22 \\
\hline 31.64 & 0.04 & -0.53 & 1.40 & 2.13 \\
\hline 63.05 & 0.12 & -0.62 & 2.40 & 3.32 \\
\hline 110.46 & 0.38 & -1.37 & -1.44 & -0.48 \\
\hline 121.23 & 0.23 & -0.47 & 0.06 & 3.05 \\
\hline 146.11 & 0.79 & -0.86 & -0.16 & 0.18 \\
\hline 149.11 & 0.67 & -0.45 & -0.40 & -0.05 \\
\hline 160.71 & -0.68 & -1.03 & 3.52 & 3.73 \\
\hline 179.51 & -0.59 & -1.31 & 3.94 & 2.51 \\
\hline \multirow{2}{*}{$\begin{array}{l}\text { Depth } \\
\text { (mbsf) }\end{array}$} & $\delta^{13} \mathrm{C}$ & $\delta^{13} \mathrm{C}$ & $\delta^{18} \mathrm{O}$ & $\delta^{18} \mathrm{O}$ \\
\hline & A. baccri & L. amygdalaeformis & A. beccarii & L. amygdalaeformis \\
\hline 88.43 & -1.65 & -0.29 & 0.29 & -0.49 \\
\hline 89.16 & -1.73 & -1.69 & 0.16 & -1.01 \\
\hline 93.38 & -1.63 & 0.04 & 0.09 & 0.10 \\
\hline 94.3 & -1.08 & -0.74 & -0.10 & -0.77 \\
\hline 98.29 & -0.59 & -0.26 & 0.08 & -0.26 \\
\hline 101.01 & -1.26 & 0.35 & -0.74 & -1.06 \\
\hline 102.3 & -0.31 & 0.59 & -0.69 & -1.29 \\
\hline 109.11 & -0.78 & 0.02 & -0.77 & -1.11 \\
\hline 110.46 & -0.38 & 0.37 & -0.52 & -2.05 \\
\hline 111.96 & -0.52 & 0.41 & -0.84 & -0.62 \\
\hline 113.46 & -0.33 & 0.56 & -0.56 & -0.64 \\
\hline 117.21 & -0.64 & 0.57 & -1.37 & -0.62 \\
\hline 119.91 & -0.41 & 1.26 & -0.40 & -0.29 \\
\hline 123.49 & -1.05 & 0.71 & -0.89 & -0.76 \\
\hline 130.61 & -0.74 & -0.07 & -0.58 & -0.46 \\
\hline 146.11 & -0.57 & 0.64 & -0.17 & -0.80 \\
\hline 147.61 & -1.30 & 0.66 & 1.84 & -1.90 \\
\hline 149.11 & -0.62 & 1.07 & -0.62 & -1.28 \\
\hline 151.63 & -0.60 & 1.25 & -1.78 & -0.40 \\
\hline Depth & $\delta^{13} \mathrm{C}$ & $\delta^{13} \mathrm{C}$ & $\delta^{18} \mathrm{O}$ & $\delta^{18} \mathrm{O}$ \\
\hline (common) & B. seminuda & N. auris & B. seminuda & N. auris \\
\hline 0.6 & -0.47 & -2.48 & 1.9 & 1.71 \\
\hline 5.1 & -1.8 & -1.65 & 2.04 & 0.26 \\
\hline 7.9 & -1.68 & -3.08 & 1.7 & 1.36 \\
\hline 8.2 & -4.02 & -4.66 & 1.58 & 0.8 \\
\hline 8.5 & -2.59 & -4.17 & 1.2 & 1.56 \\
\hline 8.8 & -2.48 & -4.83 & 1.58 & 1.12 \\
\hline 9.1 & -2.32 & -5.39 & 1.43 & 1.07 \\
\hline 9.4 & -1.71 & -2.3 & 1.85 & 1.41 \\
\hline 9.7 & -1.73 & -2.53 & 2.03 & 1.72 \\
\hline
\end{tabular}


Table A1. (Continued.)

\begin{tabular}{|c|c|c|c|c|}
\hline $\begin{array}{l}\text { Depth } \\
\text { (common) }\end{array}$ & $\begin{array}{c}\delta^{13} \mathrm{C} \\
\text { B. seminuda }\end{array}$ & $\begin{array}{c}\delta^{13} \mathrm{C} \\
\text { N. auris }\end{array}$ & $\begin{array}{c}\delta^{18} \mathrm{O} \\
\text { B. seminuda }\end{array}$ & $\begin{array}{c}\delta^{18} \mathrm{O} \\
\text { N. auris }\end{array}$ \\
\hline 13.9 & -1.96 & -3.33 & 1.13 & 1.34 \\
\hline 16.8 & -2.17 & -2.62 & 1.8 & 1.07 \\
\hline 17.7 & -1.6 & -1.67 & 2.1 & 1.69 \\
\hline 18.3 & -1.55 & -2.34 & 1.53 & 0.11 \\
\hline 18.6 & -2.23 & -2.66 & 1.37 & 1.35 \\
\hline 22.2 & -2.14 & -4.56 & 1.18 & 0.79 \\
\hline 22.5 & -2.71 & -3.42 & 1.47 & 1.15 \\
\hline 22.8 & -2.89 & -5.55 & 1.46 & 1.37 \\
\hline 26 & -1.24 & -1.36 & 1.79 & 1.11 \\
\hline 26.3 & -1.02 & -2.39 & 1.65 & 0.3 \\
\hline 26.6 & -1.45 & -3.77 & 1.66 & 0.81 \\
\hline 26.9 & -1.31 & -2.17 & 1.25 & 0.91 \\
\hline 27.8 & -1.21 & -2.4 & 1.64 & -0.01 \\
\hline 28.1 & -1.14 & -2.28 & 1.5 & 0.86 \\
\hline 28.4 & -0.9 & -1.85 & 1.82 & 1.14 \\
\hline 28.7 & -0.95 & -1.85 & 1.91 & 0.65 \\
\hline 29 & -0.81 & -1.88 & 1.7 & 0.39 \\
\hline 29.9 & -0.92 & -1.8 & 1.98 & 1.2 \\
\hline
\end{tabular}

\section{References}

Barbieri R and Panieri G 2004 How are benthic foraminiferal faunas influenced by cold seeps? Evidence from the Miocene of Italy; Palaeogeogr. Palaeoclimatol. Palaeoecol. $204257-275$.

Basak C, Rathburn A E, Pérez M E, Martin J B, Kluesner J W, Levin L A, Deckker P D, Gieskes J M and Abriani M 2009 Carbon and oxygen isotope geochemistry of live (stained) benthic foraminifera from the Aleutian Margin and the Southern Australian Margin; Mar. Micropaleontol. 70 89-101.

Bemis B E, Spero H J, Bijma J and Lea D W 1998 Re-evaluation of the oxygen isotopic composition of planktonic foraminifera: Experimental results and revised temperature equations; Paleoceanography 13 150-160.

Berger W H, Killingley J S and Vincent E 1978 Stable isotopes in deep sea carbonates: Box core ERDC 92 west equatorial Pacific; Oceanologica Acta 1 203-216.

Bernhard J M, Sen Gupta B K and Borne P F 1997 Benthic foraminiferal proxy to estimate dysoxic bottom-water oxygen concentrations: Santa Barbara Basin, U.S. Pacific continental margin; J. Foram. Res. 27 301-310.

Bhaumik A K, Gupta A K and Thomas E 2011 Blake outer ridge: Late Neogene variability in paleoceanography and deep-sea biota; Palaeogeogr. Palaeoclimatol. Palaeoecol. $302435-451$.

Bhaumik A K, Gupta A K, Clemens S C and Mazumder R 2014 Functional morphology of Melonisbarleeanum and Hoeglundinaelegans: A proxy for water-mass characteristics; Curr. Sci. 106(8) 1133-1140.

Brückner S and Mackensen A 2008 Organic matter rain rates, oxygen availability, and vital effects from benthic foraminiferal $\delta^{13} \mathrm{C}$ in the historic Skagerrak, North Sea; Mar. Micropaleontol. 66 192-207.

Collett T, Riedel M, Cochran J, Boswell R, Presley J, Kumar P, Sathe A, Sethi A, Lall M V, Sibal V and NGHP Expedition 01 Scientists 2007 Indian National Gas Hydrate
Program Expedition 01 Initial Reports; Directorate General of Hydrocarbons, Ministry of Petroleum and Natural Gas (India), Chapter 10-13, 150p.

Cooke S and Rohling E J 2001 Stable Isotopes in Foraminiferal Carbonate; Southampton Oceanography Centre Internal Document $\mathbf{7 2}$ 1-40.

Corliss B H 1985 Microhabitats of benthic foraminifera within deep-sea sediments; Nature 314 435-438.

Corliss B H 1991 Morphology and microhabitat preferences of benthic foraminifera from the northwest Atlantic Ocean; Mar. Micropaleontol. 17 195-236.

Corliss B H and Emerson S 1990 Distribution of Rose Bengal stained deep-sea foraminifera from the Nova Scotia continental margin and Gulf of Maine; Deep-Sea Res. 37 387-400.

De S and Gupta A K 2010 Deep-sea faunal provinces and their inferred environments in the Indian Ocean based on distribution of recent benthic foraminifera; Palaeogeogr. Palaeoclimatol. Palaeoecol. 291 429-442.

Debenay J-P, Bénéteau E, Zhang J, Stouff V, Geslin E, Redois F and Fernandez-Gonzalez M 1998 Ammonia beccarii and Ammonia tepida (Foraminifera): Morphofunctional arguments for their distinction; Mar. Micropaleontol. 34 235-244.

de Nooijer L J, Toyofuku T and Kitazato H 2009 Foraminifera promote calcification by elevating their intracellular pH; Proc. Nat. Acad. Sci. 106 15,374-15, 378.

Duijnstee I A P 2001 Experimental ecology of foraminifera towards better quantitative paleoecological reconstructions; PhD Dissertation, Faculty of Earth Sciences, Utrecht University, The Netherlands.

Elderfield H, Ferretti P, Greaves M, Crowhurst S, McCave I N, Hodell D and Piotrowski A M 2012 Evolution of ocean temperature and ice volume through the mid-Pleistocene climate transition; Science 337 704-709.

Emiliani C 1955 Pleistocene temperatures; J. Geol. 63 $538-578$. 
Epstein S, Buchsbaum R, Lowenstam H A and Urey H C 1953 Revised carbonate-water isotopic temperature scale; Geol. Soc. Am. Bull. 64 1315-1325.

Fontanier C, Mackensen A, Jorissen F J, Anschutz P, Licari L and Griveaud C 2006 Stable oxygen and carbon isotopes of live benthic foraminifera from the Bay of Biscay: Microhabitat impact and seasonal variability; Mar. Micropaleontol. 58 159-183.

Gabel B 1971 Die Foraminiferen der Nordsee. Helgol; Wiss. Meeresunters 22 1-65.

GEOSECS 1983 India Ocean Expedition, Hydrographic data, 1977; U.S. Govt. Printing Office, Washington DC, 5, p. 48.

Gooday A J, Bernhard J M, Levin L A and Suhr S B 2000 Foraminifera in the Arabian Sea oxygen minimum zone and other oxygen deficient settings: Taxonomic composition, diversity, and relation to metazoan faunas; Deep-Sea Res. II $4724-54$.

Graham D W, Corliss B H, Bender M L and Keigwin Jr L D 1981 Carbon and oxygen isotopic disequilibria of recent deep-sea benthic foraminifera; Mar. Micropaleontol. 6 483-497.

Grossman E L 1987 Stable isotopes in modern benthic foraminifera: A study of vital effect; J. Foram. Res. 17(1) $48-61$.

Haug G H and Tiedemann R 1998 Effect of the formation of the Isthmus of Panama on Atlantic Ocean thermohaline circulation; Nature 393 673-676.

Hill T M, Kennett J P and Spero H J 2003 Foraminifera as indicators of methane-rich environments: A study of modern methane seeps in Santa Barbara Channel, California; Mar. Micropaleontol. 49 23-138.

Hill T M, Kennett J P and Valentine D L 2004 Isotopic evidence for the incorporation of methane-derived carbon into foraminifera from modern methane seeps, Hydrate Ridge, Northeast Pacific; Geochim. Cosmochim. Acta 68 4619-4627.

Hoogakker B, Elderfield H, Oliver K and Crowhurst S 2010 Benthic foraminiferal oxygen isotope offsets over the last glacial-interglacial cycle; Paleoceanogr. 25 PA4229, doi: 10.1029/2009PA001870.

Hottinger L 2000 Functional morphology of benthic foraminiferal shells, envelopes of cells beyond measure; Micropaleontol. 46 57-86.

Ishimura T, Tsunogai U, Hasegawa S, Nakagawa F, Oi T, Kitazato H, Suga H and Toyofuku T 2012 Variation in stable carbon and oxygen isotopes of individual benthic foraminifera: Tracers for quantifying the magnitude of isotopic disequilibrium; Biogeosci. 9 4353-4367.

Jarke J 1961 Die BeziehungenzwischenhydrographischenVerhiiltnissen, Faziesentwicklung und Foraminiferenverbreitung in der heutigenNordseealsvorbildfilr die Verhiiltnissewiihrend der Miociin-Zeit; Meyniana 10 21-36.

Jorissen F J, de Stigter H C and Widmark J G V 1995 A conceptual model explaining benthic foraminiferal microhabitats; Mar. Micropaleontol. 26 3-15.

Katz M E, Katz D R, Wright J D, Miller K G, Pak D K, Shackleton N J and Thomas E 2003 Early Cenozoic benthic foraminiferal isotopes: Species reliability and interspecies correction factors; Paleoceanogr. 18(2) 1024, doi: 10.1029/2002PA000798.
Lane G A and Doyle M 1956 Fractionation of oxygen isotopes during respiration; Science 123574.

Lobegeier M K and Sen Gupta B K 2008 Foraminifera of hydrocarbon seeps, Gulf of Mexico; J. Foram. Res. 38 93-116.

Mackensen A 2008 On the use of benthic foraminiferal $\delta^{13} \mathrm{C}$ in palaeoceanography: Constraints from primary proxy relationships; Geol. Soc. London, Spec. Publ. 303 121133.

Marchitto T M, Curry W B, Lynch-Stieglitz J, Bryan S P, Cobb K M and Lund D C 2014 Improved oxygen isotope temperature calibrations for cosmopolitan benthic foraminifera; Geochim. Cosmochim. Acta 130 1-11.

Martin R A, Nesbitt E A and Campbell K A 2007 Carbon stable isotopic composition of benthic foraminifera from Pliocene cold methane seeps, Cascadia accretionary margin; Palaeogeogr. Palaeoclimatol. Palaeoecol. 246 260-277.

McConnaughey T $1989{ }^{13} \mathrm{C}$ and ${ }^{18} \mathrm{O}$ isotopic disequilibrium in biological carbonates. II: In vitro simulation of kinetic isotope effects; Geochim. Cosmochim. Acta $\mathbf{5 3}$ 163-171.

McCrea J M 1950 On the isotope chemistry of carbonates and a paleotemperature scale; J. Chem. Phys. 18 849-857.

Moberly R 1968 Composition of magnesium calcites algae and pelecypods by electron microprobe analysis, Sedimentology 11 61-82, doi: 10.1111/j.1365-3091.1968.tb00841.x.

Moodley L, Boschker H T S, Middelburg J J, Pel R, Herman P M J, de Deckere E and Heip C H R 2000 Ecological significance of benthic foraminifera: ${ }^{13} \mathrm{C}$ labelling experiments; Mar. Ecol. Progr. Ser. 202 289-295.

Mukherjee A, Shankar D, Fernando V, Amol P, Aparna S G, Farnendes R, Michael G S, Khalap S T, Satelkar N P, Agarvadekar Y, Gaonkar M G, Tari A P, Kankonkar A and Vernekar S 2014 Observed seasonal and intraseasonal variability of the East India Coastal Current on the continental slope; J. Earth Syst. Sci. 123(6) 1197-1232.

Murray J W 2006 Ecology and application of benthic foraminifera; Cambridge University Press, pp. 220-221.

Oberhänsli H, Heinze P, Diester-Haass L and Wefer G 1990 Upwelling off Peru during the last 430,000 yr and its relationship to the bottom-water environment, as deduced from coarse grain-size distributions and analyses of benthic foraminifers at holes 679D, 680B, and 681B, Leg 112, Proc. Ocean Drill. Prog. Scientific Results (eds) Suess E and von Huene $\mathrm{R}$ et al,112 369-390.

Rathburn A E, Corliss B H, Tappa K D and Lohmann K C 1996 Comparisons of the ecology and stable isotopic compositions of living (stained) benthic foraminifera from the Sulu and South China Seas; Deep-Sea Res. Part I. Oceanogr. Res. Papers 43(10) 1617-1646.

Rathburn A E, Levin L A, Held Z and Lohmann K C 2000 Benthic foraminifera associated with cold methane seeps on the northern California margin: Ecology and stable isotopic composition; Mar. Micropaleontol. 38 247-266.

Ravelo A C and Hillaire-Marcel C 2007 The use of oxygen and carbon isotopes of foraminifera in paleoceanography; Dev. Mar. Geol. 1 735-764.

Rohling E J, Foster G L, Grant K M, Marino G, Roberts A P, Tamisiea M E and Williams F 2014 Sea-level and deep-sea-temperature variability over the past 5.3 million years; Nature 508 477-482. 
Ryan T P 1997 Modern Regression Methods; John Wiley and Sons, New York.

Saraswati P K, Seto K and Nomura R 2004 Oxygen and carbon isotopic variation in co-existing larger foraminifera from Reef flat at Akajima, Okinawa, Japan; Mar. Micropaleontol. 50 339-349.

Schmiedl G and Mackensen A 2006 Multispecies stable isotopes of benthic foraminifers reveal past changes of organic matter decomposition and deepwater oxygenation in the Arabian Sea; Paleoceanogr. 21(4) PA4213.

Sen Gupta B K and Machain-Castillo M L 1993 Benthic foraminifera in oxygen-poor habitats; Mar. Micropaleontol. 20 183-201.

Shackleton N J 1974 Attainment of isotopic equilibrium between ocean water and the benthonic foraminifera genus Uvigerina: Isotopic changes in the ocean during the last glacial; CNRS, Colloq. Int. 219 203-209.

Shackleton N J 1977 The oxygen isotope stratigraphic record of the Late Pleistocene; Phil. Trans. Roy. Soc. London B280 169-182.

Shackleton N J 2000 The 100,000-year ice-age cycle identified and found to lag temperature, carbon dioxide, and orbital eccentricity; Paleoceanogr. 25 PA1211, doi: 10. 1029/2009PA001833.

Shackleton N J and Opdyke N D 1973 Oxygen isotope and paleomagnetic stratigraphy of equatorial Pacific core V28238: oxygen isotope temperatures and ice volumes on a 105 and 106 year scale; Quat. Res. 3 39-55.

Shackleton N J, Hall M A and Boersma A 1984 Oxygen and carbon isotope data from Leg 74 foraminifers; DSDP Initial Report $\mathbf{7 4}$ 599-612.

Skinner L C and Shackleton N J 2006 Deconstructing Terminations I and II: Revisiting the glacioeustatic paradigm based on deep-water temperature estimates; Quat. Sci. Rev. 25 3312-3321.

Spero H J and Lea D W 1996 Experimental determination of stable isotope variability in Globigerina bulloides:
Implications for paleoceanographic reconstructions; Mar. Micropaleontol. 28 231-246.

Spero H J, Bijma J, Lea D W and Bemis B E 1997 Effect of seawater carbonate concentration on foraminiferal carbon and oxygen isotopes; Nature 390 497-500.

Stefanelli S, Capotondi L and Ciaranfi N 2005 Foraminiferal record and environmental changes during the deposition of the early-middle Pleistocene sapropels in southern Italy; Palaeogeogr. Palaeoclimatol. Palaeoecol. 216 $27-52$.

Suess E, von Huene $\mathrm{R}$ and Shipboard Scientific Party et al. 1988 Proceedings of Ocean Drilling Program, Initial Reports, 112: College Station, TX (Ocean Drilling Program), 112 249-303.

Tchernia P 1980 Descriptive Regional Oceanography; Pergamon, New York, 253p.

Torres M E, Mix A C, Kinports K, Haley B, Klinkhammer G P, McManus J and de Angelis M A 2003 Is methane venting at the seafloor recorded by $\delta^{13} \mathrm{C}$ of benthic foraminifera shells? Paleoceanogr. 18 1062, doi: 10. 1029/2002PA000824.

Urey H C 1947 The thermodynamic properties of isotopic substances; J. Chem. Soc. pt. 1 562-581.

Wefer G and Berger W H 1991 Isotope paleontology: Growth and composition of extant calcareous species; Mar. Geol. $100207-248$.

Wefer G, Heinze P-M and Berger W H 1994 Clues to ancient methane release; Nature 369282.

Woodruff F, Savin S M and Douglas R G 1980 Biological fractionation of oxygen and carbon isotopes by recent benthic foraminifera; Mar. Micropaleontol. 5 3-11.

Wyrtki K 1971 Oceanographic Atlas of the International Indian Ocean Expedition; National Science Foundation, Washington, DC, 531p.

Zachos Z, Pagani M, Sloan L, Thomas E and Billups K 2001 Trends, rhythms, and aberrations in global climate $65 \mathrm{Ma}$ to Present; Science 292 686-693. 